\title{
ОПЫТ МИКОТОКСИКОЛОГИЧЕСКОГО ОБСЛЕДОВАНИЯ ЗЕРНОФУРАЖНЫХ КУЛЬТУР
}

\section{Г.П. КОНОНЕНКО $\bowtie$, Е.В. ЗОТОВА, А.А БУРКИН}

В последние годы в Российской Федерации отмечается устойчивый рост объемов заготовки кормов из вегетативной массы зернофуражных культур (З.Л. Федорова, Л.В. Романенко, 2016; В.В. Попов, 2017; Е.А. Волкова с соавт., 2018). Для успешного и безопасного использования этих продуктов консервирования чрезвычайно важно не только строго соблюдать рекомендованные сроки, высоту скашивания, условия высушивания и технологию закладки зерностеблевой массы, но и располагать наиболее полной информацией о санитарном качестве сырья. Уже начато изучение особенностей контаминации токсигенными микроскопическими грибами и микотоксинами дикорастущих и посевных злаков (Г.Ю. Лаптев с соавт., 2014; А.А. Буркин, Г.П. Кононенко, 2015; G.P. Kononenko c соавт., 2015; Е.А. Йылдырым с соавт., 2019), однако исследование зернофуражных культур в этом аспекте не проводилось. В настоящей работе впервые получены сведения о характере контаминации вегетирующих зернофуражных культур токсичными метаболитами микроскопических грибов и направленности изменений в содержании микотоксинов при смене фаз развития растений, а также в колосьях в начальный период созревания зерна. Целью работы было микотоксикологическое обследование вегетирующих растений ячменя, пшеницы и овса в сроки, оптимальные для заготовки на сено и зерносенаж, и незрелых колосьев ячменя и пшеницы. Яровой ячмень (Hordeum vulgare L.) сорта Владимир, яровую мягкую пшеницу (Triticum aestivum L.) сорта Иволга и овес посевной (Avena sativa L.) сорта Скакун собирали с 24 апреля по 11 августа 2019 года на полях РГАУ-МСХА им. К.А. Тимирязева (г. Москва) и ФНЦ кормопроизводства и агроэкологии им. В.Р. Вильямса (Московская обл.). К І периоду относили сборы от начала кущения до стадии лигулы (листового языка), ко ІІ периоду - от открытия листового влагалища флагового листа и появления остей над лигулой до ранней молочной спелости колосьев. Наземные части срезали на расстоянии 3-5 см от поверхности почвы, колосья отделяли от растений ячменя и пшеницы на стадии созревания зерен. Содержание микотоксинов - Т-2 токсина (Т-2), дезоксиниваленола (ДОН), зеараленона (ЗЕН), фумонизинов (ФУМ), эргоалкалоидов (ЭА), альтернариола (АОЛ), роридина А (РОА), афлатоксина В1 (АВ1), стеригматоцистина (СТЕ), циклопиазоновой кислоты (ЦПК), эмодина (ЭМО), охратоксина А (ОА), цитринина (ЦИТ), микофеноловой кислоты (MФК), PR-токсина (PR) - анализировали с помощью аттестованных иммуноферментных тест-систем. У вегетирующих зернофуражных культур нагрузка микотоксинами в целом была охарактеризована как низкая. Регулярно присутствовали АОЛ, ЭМО в малых и сопоставимых количествах - соответственно 15-32 и 14-29 мкг/кг, а также ЦПК и ЭА с более широкими пределами варьирования - 34-180 и 2-115 мкг/кг. Фузариотоксины Т-2, ДОН, ЗЕН встречались в единичных образцах, а ФУМ не были обнаружены. POA также отсутствовал, РR удалось детектировать лишь в одном образце пшеницы. В фитомассе всех культур были найдены МФК и СТЕ, содержание которых соответствовало десяткам микрограммов на 1 кг, а также АВ1 в фоновых количествах 1-3 мкг/кг. Случаи совместной контаминации ОА и ЦИТ отмечены только у ячменя и чаще на стадиях кущения и лигулы, а у пшеницы и овса редко находили только ОА в количествах, близких пределу детектирования. Вегетирующий овес в менышей степени был подвержен контаминации микотоксинами, чем ячмень и пшеница, что особенно важно в практическом аспекте, поскольку этот злак чаще возделывают на зеленый корм как в чистом виде, так и в поливидовых посевах для последующего консервирования зеленой массы. Колосья пшеницы и ячменя в начале фазы созревания заметно отличались от надземных частей растений: в них наблюдалась единообразная тенденция к снижению частоты выявления микотоксинов до единичных случаев или их полного отсутствия при сохранении встречаемости ЭМО.

Ключевые слова: пшеница, ячмень, овес, фитомасса, микотоксины, иммуноферментный анализ.

В последние годы в ряде регионов Российской Федерации отмечается рост объемов заготовки кормов из вегетативной массы зернофуражных культур (пшеницы, ячменя, овса, тритикале), что объясняется высокой питательной ценностью продуктов ее консервирования и возможностью успешного преодоления критических ситуаций, угрожающих сбору полно- 
ценного урожая зерна (1-3). Для эффективного и безопасного использования сена и сенажа из зернофуражных культур чрезвычайно важно не только строго соблюдать рекомендованные сроки, высоту скашивания, условия высушивания и технологию закладки зерностеблевой массы, но и располагать наиболее полной информацией о санитарном качестве сырья. Особую значимость имеют сведения о пораженности растений токсигенными микроскопическими грибами и их метаболитами, которые приводят к возникновению микотоксикозов животных $(4,5)$. Для многочисленного сообщества злаков накопление такой информации только начинается. Изучена встречаемость грибов Fusarium в травостоях провинции Манитоба в Канаде (6) и Хорватии (7). Дана оценка распространенности этих грибов и их токсинов в 70 видах луговых растений в одной из экосистем, пригодных для выпаса скота, в провинции Чако на северо-востоке Аргентины $(8,9)$. Определены систематическая принадлежность и токсигенный потенциал грибов Fusarium из микобиоты девяти видов трав в пяти агроэкологических зонах западной части Ирана (10).

Российскими исследователями, наряду с изучением контаминации луговых бобовых трав грибами Fusarium, Alternaria, Cladosporium и микотоксинами $(11,12)$, описаны особенности колонизации этими грибами дикорастущих и культурных злаков (13), а также общая микотоксикологическая ситуация для сообщества луговых растений (14) и производственного смесевого посева райграса, тимофеевки, овсяницы, фестуллолиума и ежи сборной (15). Проведен анализ содержания пяти микотоксинов в образцах с монопосевов райграса и тимофеевки $(16,17)$. Зернофуражные культуры, которые убирают без обмолота на кормовые цели, ранее не изучались.

В настоящей работе впервые получены сведения о характере контаминации вегетирующих зернофуражных культур токсичными метаболитами микроскопических грибов, а также о направленности изменений в содержании микотоксинов при смене фаз развития растений и в колосьях в начальный период созревания зерна.

Целью работы было микотоксикологическое обследование вегетирующих растений ячменя, пшеницы и овса в сроки, оптимальные для заготовки на сено и зерносенаж, а также незрелых колосьев ячменя и пшеницы.

Методика. Яровой ячмень (Hordeum vulgare L.) сорта Владимир, яровую мягкую пшеницу (Triticum aestivum L.) сорта Иволга и овес посевной (Avena sativa L.) сорта Скакун собирали с 24 апреля по 11 августа 2019 года на полях РГАУ_МСХА им. К.А. Тимирязева (г. Москва) и ФНЦ кормопроизводства и агроэкологии им. В.Р. Вильямса (Московская обл.).

Для описания фенофаз растений использовали классификацию по системе ВВСН (18). К I периоду относили сборы от начала кущения до стадии лигулы (листового языка) (ВВСН 21-39), ко II периоду - от открытия листового влагалища флагового листа и появления остей над лигулой до ранней молочной спелости колосьев (ВВСН 49-73). Наземные части срезали на расстоянии 3-5 см от поверхности почвы, колосья отделяли от растений ячменя и пшеницы на стадии созревания зерен (восковая спелость, ВВСН 83-87).

Образцы выдерживали до воздушно-сухого состояния в проветриваемом помещении и измельчали в лабораторной мельнице M20 («IKA», Германия). Для экстракции применяли смесь ацетонитрила и воды в объемном соотношении 84:16 при расходе 10 мл на 1 г навески. Экстракты после 10кратного разбавления буферным раствором использовали для непрямого конкурентного иммуноферментного анализа. Содержание микотоксинов - 
Т-2 токсина (Т-2), дезоксиниваленола (ДОН), зеараленона (ЗЕН), фумонизинов (ФУМ), эргоалкалоидов (ЭА), альтернариола (АОЛ), роридиа А (РОА), афлатоксина В1 (АВ1), стеригматоцистина (СТЕ), циклопиазоновой кислоты (ЦПК), эмодина (ЭМО), охратоксина А (ОА), цитринина (ЦИТ), микофеноловой кислоты (MФК), PR-токсина (PR) определяли с помощью аттестованных иммуноферментных тест-систем (ГОСТ 31653-2012 «Корма. Метод иммуноферментного определения микотоксинов». М., 2012). Нижние пределы количественных измерений соответствовали 85 \% уровню связывания антител.

Полученные данные обрабатывали с помощью описательной статистики в программе Microsoft Excel 2013, вычисляли долю положительных образцов $\left(n^{+}\right)$от числа исследованных $(n)$, минимальное, максимальное содержание микотоксина (мкг/кг) и среднее арифметическое значение $(M)$ по положительным образцам.

Результаты. В обследованных злаках не удалось обнаружить микотоксины ФУМ и POA. PR был найден лишь в одном образце пшеницы в количестве 320 мкг/кг. Сходная ситуация с единичными случаями детектирования PR и отсутствием ФУМ и POA недавно описана для дикорастущих однолетников семейства Крестоцветные (19), а также у посевной горчицы белой (20) и подсолнечника (21). К сожалению, сведения по контаминации зеленой массы кукурузы пока крайне ограничены: в четырех исследованных образцах из Ростовской области, находящихся в стадиях 3 листьев, завершения цветения и физиологической спелости, не были выявлены ФУМ и POA (неопубликованные данные авторов). Тем не менее известно, что в начале роста для кукурузы и риса характерно инфицирование грибами $M y$ rothecium spp., продуцирующими РОА (22).

К числу наиболее часто детектируемых микотоксинов в нашем исследовании относились АОЛ, ЦПК и ЭА, при этом у пшеницы этот перечень пополняли МФК и ЭМО, у овса - ЭМО, у ячменя - АВ 1 , СТЕ и МФК. Кроме того, у ячменя, в отличие от пшеницы и овса, регулярно обнаруживали ОА и ЦИТ. Фузариотоксины Т-2, ДОН, ЗЕН были выявлены в единичных образцах (табл. 1).

1. Встречаемость и содержание микотоксинов в вегетирующих растениях ярового ячменя (Hordeum vulgare L.) сорта Владимир, яровой мягкой пшеницы (Triticum aestivum L.) сорта Иволга и овса посевного (Avena sativa L.) сорта Скакун (Московская обл., 2019 год)

\begin{tabular}{|c|c|c|c|c|c|c|}
\hline \multirow[b]{2}{*}{ Микотоксин } & \multicolumn{2}{|c|}{ Ячмень $(n=32)$} & \multicolumn{2}{|c|}{ Пшеница $(n=11)$} & \multicolumn{2}{|c|}{ Овес $(n=11)$} \\
\hline & $\begin{array}{c}\mathrm{I} \\
(n=14)\end{array}$ & $\begin{array}{c}\text { II } \\
(n=18)\end{array}$ & $\begin{array}{c}\mathrm{I} \\
(n=2)\end{array}$ & $\begin{array}{c}\text { II } \\
(n=9)\end{array}$ & $\begin{array}{c}\mathrm{I} \\
(n=3)\end{array}$ & $\begin{array}{c}\text { II } \\
(n=8)\end{array}$ \\
\hline $\mathrm{T}-2$ & - & - & - & $\begin{array}{l}2 \\
3\end{array}$ & $\begin{array}{l}2 \\
2\end{array}$ & - \\
\hline дОН & $\begin{array}{c}1 \\
95\end{array}$ & - & - & - & - & $\begin{array}{c}1 \\
160\end{array}$ \\
\hline 3EH & - & - & $\begin{array}{c}2 \\
32\end{array}$ & - & - & - \\
\hline ЭА & $\begin{array}{c}14 \\
7-16-37\end{array}$ & $\begin{array}{c}17 \\
2-8-35\end{array}$ & $\begin{array}{l}1 \\
3\end{array}$ & $\begin{array}{c}7 \\
6-115-425\end{array}$ & $\begin{array}{l}2 \\
6\end{array}$ & $\begin{array}{c}4 \\
1-2-2\end{array}$ \\
\hline АОЛ & $\begin{array}{c}14 \\
18-30-49\end{array}$ & $\begin{array}{c}18 \\
13-29-40\end{array}$ & $\begin{array}{c}2 \\
27\end{array}$ & $\begin{array}{c}7 \\
16-26-32\end{array}$ & $\begin{array}{c}2 \\
32\end{array}$ & $\begin{array}{c}4 \\
15-21-25\end{array}$ \\
\hline $\mathrm{AB} 1$ & $\begin{array}{c}6 \\
2-3-3\end{array}$ & $\begin{array}{c}15 \\
2-2-3\end{array}$ & - & $\begin{array}{c}4 \\
1-1-2\end{array}$ & - & $\begin{array}{l}2 \\
1\end{array}$ \\
\hline CTE & $\begin{array}{c}7 \\
13-24-25\end{array}$ & $\begin{array}{c}9 \\
13-16-22\end{array}$ & - & $\begin{array}{c}4 \\
16-20-25\end{array}$ & $\begin{array}{c}1 \\
13\end{array}$ & - \\
\hline ЦПК & $\begin{array}{c}13 \\
79-180-320\end{array}$ & $\begin{array}{c}16 \\
76-145-265\end{array}$ & $\begin{array}{c}2 \\
81\end{array}$ & $\begin{array}{c}9 \\
66-140-280\end{array}$ & $\begin{array}{c}2 \\
89\end{array}$ & $\begin{array}{c}4 \\
27-48-70\end{array}$ \\
\hline ЭМО & $\begin{array}{c}6 \\
11-14-18\end{array}$ & $\begin{array}{c}7 \\
11-17-25\end{array}$ & - & $\begin{array}{c}5 \\
10-14-19\end{array}$ & $\begin{array}{c}2 \\
18\end{array}$ & $\begin{array}{c}6 \\
16-29-40\end{array}$ \\
\hline
\end{tabular}


$\mathrm{OA}$

ЦИТ

МФК
58

$6-8-10$

7

$19-23-33$

5

19-23-30
4-5-6

1

30

\begin{tabular}{cc}
- & 2 \\
- & 5 \\
1 & - \\
21 & 8 \\
\hline
\end{tabular}

Продолжение таблицы 1

7

$-$

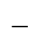

$-$

П р и м е ч а н и е. Т-2 - Т-2 токсин, ДОН - дезоксиниваленол, ЗЕН - зеараленон, ЭА - эргоалкалоиды, АОЛ - альтернариол, АВ1 - афлатоксин В1, СТЕ - стеригматоцистин, ЦПК - циклопиазоновая кислота, ЭМО - эмодин, ОА - охратоксин А, ЦИТ - цитринин, МФК - микофеноловая кислота. Период I - от стадии кущения до стадии лигулы (листового языка) (ВВСН 21-39), период II - от стадии открытия листового влагалища фагового листа и появления остей над лигулой до ранней молочной спелости колосьев (ВВСН 49-73); $n$ - число исследованных образцов. Верхняя цифра в строках - число положительных образцов $\left(n^{+}\right)$, содержащих микотоксины в количестве, превышающем нижний предел измерений; под ним указано содержание соответствующего микотоксина (мкг/кг, минимальное-среднее-максимальное). Прочерк означает, что микотоксин не обнаружен.

У вегетирующего овса во всех образцах не удалось выявить ни один из токсинов, возможно, из-за низких содержаний, близких к пределам определения. Факт слабо выраженной контаминации микотоксинами этой культуры весьма важен в практическом аспекте, поскольку овес чаще возделывают на зеленый корм как в чистом виде, так и в смесевых посевах с викой, горошком и чиной.

Границы наблюдений за микотоксикологическим статусом зернофуражных культур были выбраны с учетом рекомендованных сроков их заготовки на сено (I период, окончание не позднее развития кроющего флагового листа) и на зерносенаж (II период, завершение в начале молочно-восковой спелости зерна).

По сопоставимым выборкам образцов ячменя за I и II периоды можно составить общее представление о направленности изменений в контаминации микотоксинами (см. табл. 1). В оба периода среднее содержание микотоксинов, рассчитанное по положительным образцам, оставалось сопоставимым. Так, количества АОЛ, ЭМО были одинаково низкими (от 14 до 30 мкг/кг), загрязненность ОА - фоновой, ЭА содержались в малых концентрациях от единиц до десятков мкг/кг. Тем не менее I период отличался от II периода по числу случаев детектирования ЦИТ, МФК и АВ1. В начальную фазу растениям было свойственно повышенное накопление ЦИТ и пониженное - МФК и АВ1. Следует отметить, что у пшеницы и овса в отношении МФК и АВ1 прослеживалась та же тенденция (см. табл. 1). Варьирование содержания микотоксинов по периодам роста указывает на возможную причастность токсигенных микромицетов к процессам, сопровождающим смену онтогенетических состояний этих растений. Однако провести поиск каких-либо соответствий с составом их микобиоты пока не представляется возможным из-за отсутствия базовых сведений. Как известно, микотоксины продуцируют многие виды из родов Alternaria, Fusarium, Aspergillus, Penicillium, а также другие грибы, способные к автономному существованию (23-26). Возможно, часть из них адаптирована к обитанию внутри растений (27-29) и в состоянии обеспечивать биосинтез этих метаболитов самостоятельно или с участием организмахозяина (30).

Во II период у ячменя, пшеницы и овса содержание АОЛ, ЭМО и МФК было одинаково низким и стабильным (от 14 до 29 мкг/кг), загрязненность ОА и ЦИТ - фоновой или отсутствовала. ЭА находили, как правило, в малых концентрациях от единиц до десятков мкг/кг, за исключением нескольких случаев превышения значения 100 мкг/кг у пшеницы (см. табл. 1). Возможно, причиной было инфицирование части колосьев активно продуцирующими эпифитами рода Claviceps (31). У пшеницы и ячменя раз- 
личий по встречаемости и степени контаминации $\mathrm{AB}_{1}$ (соответственно 1 и 2 мкг/кг), СТЕ (20 и 24 мкг/кг) и ЦПК (140 и 145 мкг/кг) не отмечалось. У овса АВ1 встречался еще реже, СТЕ отсутствовал, а содержание ЦПК было на порядок меньшим (48 мкг/кг). В целом зерностеблевая масса у всех трех культур характеризовалась умеренной контаминацией и по этому показателю может быть признана одинаково перспективной для закладки на зерносенаж. Укосы овса на поздних сроках вегетации также пригодны для высушивания, поскольку овсяное сено сохраняет высокую питательность на всех этапах зрелости растений.

В целом по нагрузке микотоксинами вегетативная масса зернофуражных культур мало отличается от слабо контаминированных крестоцветных растений и подсолнечника (19-21). Тот факт, что как у однодольных, так и двудольных растений мы регулярно выявляли АОЛ, ЭА и ЦПК, позволяет предположить наличие сходства в составе их микобиоты. Действительно, среди эндофитов многих растений описаны грибы с подтвержденным потенциалом биосинтеза АОЛ и ЭА (32), однако каких-либо сведений об идентификации активных продуцентов ЦПК (33) в составе внутренней микофлоры трав в доступной литературе найти не удалось.

Различия по профилю микотоксинов по некоторым видам растений, а также у сообществ с годичным и прерываемым циклом развития указывают на особенности в составе ассоциированных грибов.

В последние годы идет активное накопление сведений о видовом разнообразии эндофитов с применением молекулярных методов, в частности у представителей трибы Triticeae (34), тростника обыкновенного Phragmites australis (Cav.) Trin. ex Steud. (35), бамбука Phyllostachys spp., Sasa spp. (36), чия сибирского Achnatherum sibiricum (L.) Keng ex Tzvelev (37, 38), ежи сборной Dactylis glomerata L. (39). Установлено, что у культурных злаков (райграсс, тимофеевка, пшеница) содержание ДНК грибов Alternaria и Cladosporium было в 6 раз, а Fusarium - в 14 раз меньше, чем у дикорастущих (ежа, пырей, тимофеевка) (13). В дальнейшем такие методы позволят приступить к поиску конкретных микромицетов, ответственных за формирование естественного фона контаминации микотоксинами кормовых растений, включая и зернофуражные культуры.

Созревающие колосья пшеницы и ячменя заметно отличались по содержанию микотоксинов от вегетирующей фитомассы II периода (табл. 2). У ячменя чаще обнаруживали Т-2, ДОН и АОЛ, что могло быть следствием грибной инфекции, поскольку усиление контаминации этими токсинами наблюдается при интенсивной пораженности фузариозом и альтернариозом $(40,41)$. М.Д. Омельченко с соавт. (42) отмечали связь накопления ДОН с процессом созревания колосьев фузариозной пшеницы.

2. Встречаемость и содержание микотоксинов в незрелых колосьях ярового ячменя (Hordeum vulgare L.) сорта Владимир и яровой мягкой пшеницы (Triticum aestivum L.) сорта Иволга (Московская обл., 2019 год)

\begin{tabular}{lccc}
\hline & Микотоксин & Ячмень $(n=13)$ & Пшеница $(n=6)$ \\
Т-2 & 4 & - \\
дОН & $2-7-10$ & - \\
& 4 & - \\
ЗЕН & $79-150-260$ & 4 \\
& 1 & $3-9-11$ \\
ЭА & 15 & 2 \\
& 2 & 16
\end{tabular}




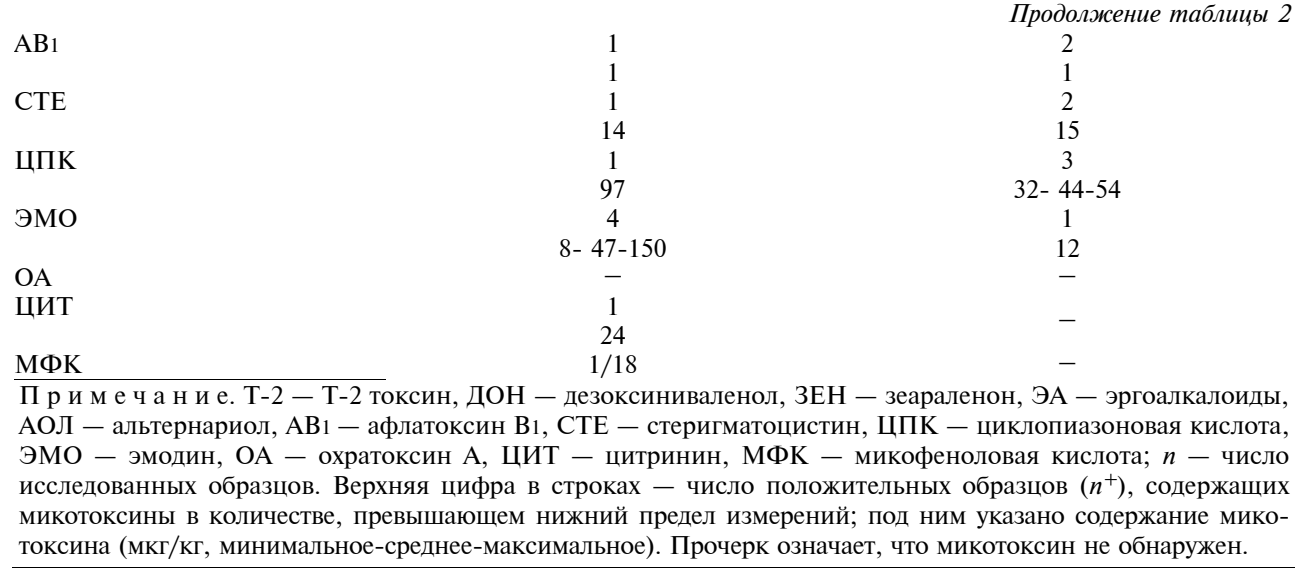

В колосьях отмечали снижение встречаемости $\mathrm{AB} 1, \mathrm{CTE}$, ЦИТ и МФК до единичных случаев или полного отсутствия (см. табл. 2). Сходная ситуация наблюдалась и для зрелого зерна пшеницы и ячменя: $\mathrm{AB} 1$ не был обнаружен, а случаи детектирования СТЕ, ЦИТ и МФК не превышали $5 \%$ (43). Контаминация колосьев пшеницы ЦПК также была значительно снижена в сравнении с фитомассой (см. табл. 2), что соответствовало полученным ранее данным о ее низкой встречаемости (1\%) в зрелом зерне (43). В колосьях ячменя этот токсин был найден лишь в одном случае, а в зерне не выявлен ни в одном из 92 образцов (43). Напротив, частота выявления ЭМО сохранялась одинаковой в созревающих колосьях и вегетативной массе (30$40 \%$ ) (см. табл. 1, 2), а в обмолоченном зерне достигала 72,3 \% (43). Учитывая разнонаправленные изменения в распределении микотоксинов между вегетативными частями и колосьями, можно допустить, что процесс созревания сопровождается блокировкой или активацией их биосинтеза ассоциированными продуцентами, переформированием состава микобиоты с замещением их другими грибами или изменением локализации токсигенных грибов в растении. Интересно, что у взрослых растений кукурузы при множественной сочетанной контаминации листьев, стеблей и цветков, в початках микотоксины отсутствовали (неопубликованные данные).

Характеристика основных зернофуражных культур по накоплению токсичных для животных метаболитов грибов, сделанная нами, важна для развития обоснованного подхода к формированию поливидовых травостоев, хозяйственная целесообразность которых не вызывает сомнений. Подобные проекты еще предстоит осуществить для кукурузы и тритикале, а также для сорговых, которые все активнее внедряются в полевое кормопроизводство. В будущем можно рассчитывать и на более подробное описание микотоксикологического статуса культур с помощью комбинированной высокоэффективной жидкостной хроматографии и масс-спектрометрии $(44,45)$. Эти методы были использованы для анализа дикорастущих трав в Норвегии (46) и успешно применялись для оценки контаминации микотоксинами урожая зерна пшеницы и ячменя 2017-2018 годов из Уральского региона (47).

Таким образом, при уборке в ранние сроки на сено и в более поздние - на зерносенаж зеленая масса пшеницы, ячменя и овса слабо контаминирована микотоксинами. Регулярная встречаемость при малом содержании установлена для альтернариола, циклопиазоновой кислоты, эмодина и эргоалкалоидов, показано присутствие в фитомассе всех культур микофе- 
ноловой кислоты и стеригматоцистина, фоновых концентраций афлатоксина В1 и отсутствие фумонизинов и роридина А. Колосья пшеницы и ячменя в начале фазы созревания заметно отличались от надземных частей растений: в них наблюдалась единообразная тенденция к снижению частоты выявления микотоксинов до единичных случаев или их полного отсутствия при сохранении встречаемости эмодина. Выявленные особенности накопления микотоксинов в начальный и завершающий периоды роста, а также в созревающих колосьях свидетельствуют об активной роли токсигенных микроскопических грибов в процессах развития растений и служат убедительным доводом в пользу необходимости проведения комплексных исследовательских проектов, направленных на расшифровку механизмов их взаимодействия с ассоциированными грибами.

\section{ЛИТ И РАТ У РА}

1. Федорова 3.Л., Романенко Л.В. Требования к качеству основных кормов для коров с высокой продуктивностью (обзор). Генетика и разведение животных, 2016, 3: 3-14.

2. Попов В.В. Корма из зерностеблевой массы фуражных культур. Адаптивное кормопроизводство, 2017, 2: 73-88.

3. Волкова Е.А., Муратов Ф.Ф., Туаева Е.В., Чурилова К.С., Рыжков В.А. Комплексная оценка эффективности производства и использования зерносенажа из зерновых злаковых культур в молочном животноводстве. Дальневосточный аграрный вестник, 2018, 3(47): 145153 (doi: 10.24411/1999-6837-2018-13070).

4. Fink-Gremmels J. Микотоксины в грубых и сочных кормах. В сб.: Микотоксины и микотоксикозы /Под ред. Д. Диаза. М., 2006: 157-178.

5. Zaki M.M., El-Midany S.A., Shaheen H.M., Rizzi L. Mycotoxins in animals: Occurrence, effects, prevention and management. Journal of Toxicology and Environmental Sciences, 2012, 4(1): 13-28 (doi: 10.5897/JTEHS11.072).

6. Inch S., Gilbert J. The incidence of Fusarium species recovered from inflorescences of wild grasses in Southern Manitoba. Canadian Journal of Plant Pathology, 2003, 25(4): 379-383 (doi: 10.1080/07060660309507093).

7. Postic J., Cosic J., Vrandecic K., Jurkovic D., Saaleh A.A., Leslie J.F. Diversity of Fusarium species isolated from weeds and plant debris in Croatia. Journal of Phytopathology, 2012, 160(2): 76-81 (doi: 10.1111/j.1439-0434.2011.01863.x).

8. Nichea M.J., Sulyok M., Krska R., Chulze S., Torres A., Ramirez M.L. Fusarium species and mycotoxins present on native grasses from a wetland ecosystem in Argentina. Proc. 13th European Fusarium Seminar dedicated to the Memory of Wally Marasas «Fusarium - pathogenicity, mycotoxins, taxonomy, genomics, biosynthesis, metabolomics, resistance, disease control». Martina Franca, Italy, 2015: 128.

9. Nichea M.J., Palacios S.A., Chiacchiera S.M., Sulyok M., Krska R. Chulze S.N., Torres A.M., Ramirez M.L. Presence of multiple mycotoxins and other fungal metabolites in native grasses from a wetland ecosystem in Argentina intended for grazing cattle. Toxins, 2015, 7(8): 3309-3329 (doi: 10.3390/toxins7083309).

10. Chehri Kh., Hajeb S., Maassoumi S.M. Morphological and molecular identification and PCR amplification to determine the toxigenic potential of Fusarium graminearum species complex (FGSC) isolated from wild grasses in Iran. Journal of Agricultural Science and Technology, 2017, 19(7): 1617-1629.

11. Орина А.С., Гаврилова О.П., Гагкаева Т.Ю. Выявление зараженности грибами однолетних и многолетних трав семейства Leguminosae методом количественной ПЦР. Вестник защиты растений, 2018, 2(96): 35-41 (doi: 10.31993/2308-6459-2018-2(96)-35-41).

12. Гаврилова О.П., Орина А.С., Гагкаева Т.Ю. Количественная оценка зараженности видов рода Trifolium грибами и контаминации микотоксинами. Агрохимия, 2017, 11: 58-66 (doi: 10.7868/S0002188117110072).

13. Орина А.С., Гаврилова О.П., Гагкаева Т.Ю. Колонизация культурных и дикорастущих злаковых растений грибами родов Alternaria, Cladosporium и Fusarium. Защита и карантин растений, 2017, 6: 25-27.

14. Буркин А.А., Кононенко Г.П. Контаминация микотоксинами луговых трав в европейской части России. Сельскохозяйственная биология, 2015, 50(4): 503-512 (doi: 10.15389/agrobiology.2015.4.503rus).

15. Kononenko G.P., Burkin A.A., Gavrilova O.P., Gagkaeva T.Yu. Fungal species and multiple mycotoxin contamination of cultivated grasses and legumes crops. Agricultural and Food Science, 2015, 24: 323-330 (doi: 10.23986/afsci.52313). 
16. Лаптев Г.Ю., Новикова Н.И., Ильина Л.А., Йылдырым Е.А., Никонов И.Н., Филиппова В.А., Бражник Е.А., Корочкина Е.А. Распространение микотоксинов в кормовом травостое и силосе. Аграрный вестник Урала, 2014, 12(130): 33-37.

17. Йылдырым Е.А., Ильина Л.А., Филиппова В.А., Новикова Н.И., Лаптев Г.Ю., Тюрина Д.Г., Солдатова В.В. Изучение распространения микотоксинов в фуражном травостое и консервированных кормах. Технологии и технические средства механизированного производства продукции растениеводства и животноводства, 2019, 3(100): 99-107 (doi: 10.24411/0131-5226-2019-10191).

18. Meier U. Growth stages of mono- and dicotyledonous plants. BBCH Monograph, 2001 (doi: 10.5073/20180906-074619).

19. Кононенко Г.П., Зотова Е.В. Метаболический профиль токсинообразующих микромицетов у луговых растений семейства Крестоцветные. Успехи медицинской микологии, 2019, 20 : 639-643.

20. Буркин А.А., Кононенко Г.П., Мосина Л.В. Первое микотоксикологическое исследование горчицы белой (Sinapis alba). Сельскохозяйственная биология, 2019, 54(1): 186-194 (doi: 10.15389/agrobiology.2019.1.186rus).

21. Зотова Е.В., Кононенко Г.П., Буркин А.А. Микотоксины в подсолнечнике (Helianthus annuus L.): компонентный состав и распределение по растению. Современная микология 6 России, 2017, 7: 202-204.

22. Мартынюк Т.Д., Егорова Л.Н. Myrothecium verrucaria - новый патоген кукурузы в Приморском крае. Микология и фитопатология, 2009, 43(5): 457-459.

23. Perrone G., Gallo A. Aspergillus species and their associated mycotoxins. In: Mycotoxigenic fungi. Methods in molecular biology, vol. 1542 /A. Moretti, A. Susca (eds.). Humana Press, New York, NY, 2017: 33-49 (doi: 10.1007/978-1-4939-6707-0_3).

24. Munkvold G.P. Fusarium species and their associated mycotoxins. In: Mycotoxigenic fungi. Methods in molecular biology, vol. 1542 /A. Moretti, A. Susca (eds.). Humana Press, New York, NY, 2017: 51-106 (doi: 10.1007/978-1-4939-6707-0 4).

25. Perrone G., Susca A. Penicillium species and their associated mycotoxins. In: Mycotoxigenic fungi. Methods in molecular biology, vol. 1542 /A. Moretti, A. Susca (eds.). Humana Press, New York, NY, 2017: 107-119 (doi: 10.1007/978-1-4939-6707-0 5).

26. Pinto V.E.F., Patriarca A. Alternaria species and their associated mycotoxins. In: Mycotoxigenic fungi. Methods in molecular biology, vol. 1542 /A. Moretti, A. Susca (eds.). Humana Press, New York, NY, 2017: 13-32 (doi: 10.1007/978-1-4939-6707-0_2).

27. Shankar N.B., Shashikala J., Krishnamurthy Y.L. Study on diversity of endophytic communities from rice (Oryza sativa L.) and their antagonistic activities in vitro. Microbiological Research, 2007, 164(3): 290-296 (doi: 10.1016/j.micres.2006.12.003).

28. Potshangbam M., Devi S.I., Sahoo D., Strobel G.A. Functional characterization of endophytic fungal community associated with Oryza sativa L. and Zea mays L. Frontiers in Microbiology, 2017, 8: 325 (doi: 10.3389/fmicb.2017.00325).

29. Lofgren L.A., LeBlanc N.R., Certano A.K., Nachtigall J., LaBine K.M., Riddle J., Broz K., Dong Y., Bethan B., Kafer C.W., Kistler H.C. Fusarium graminearum: pathogen or endophyte of North American grasses? New Phytologist, 2018, 217(3): 1203-1212 (doi: 10.1111/nph.14894).

30. Kusari S., Spiteller M., Metabolomics of endophytic fungi producing associated plant secondary metabolites: progress, challenges and opportunities In: Metabolomics /U. Roessner (ed.). InTech, London, 2012: 241-266 (doi: 10.5772/31596).

31. Florea S., Panaccione D.G., Schardl C.L. Ergot alkaloids of the family Clavicipitaceae. Phytopathology, 2017, 107(5): 504-518 (doi: 10.1094/PHYTO-12-16-0435-RVW).

32. Mishra Y., Singh A., Batra A., Sharma M.M. Understanding the biodiversity and biological applications of endophytic fungi: a review. Journal of Microbial \& Biochemical Technology, 2014, S8: 004 (doi: 10.4172/1948-5948.S8-004).

33. Ostry V., Toman J., Grosse Y., Malir F. Cyclopiazonic acid: $50^{\text {th }}$ anniversary of its discovery. World Mycotoxin Journal, 2018, 11(1): 135-148 (doi: 10.3920/WMJ2017.2243).

34. Card S.D., Faville M.J., Simpson W.A., Johnson R.D., Voisey C.R., de Bonth A.C.M., Hume D.E. Mutualistic fungal endophytes in the Triticeae - survey and description. FEMS Microbiology Ecology, 2014, 88: 94-106 (doi: 10.1111/1574-6941.12273).

35. Wirsel S.G.R., Leibinger W., Ernst M., Mendgen K. Genetic diversity of fungi closely associated with common reed. New Phytologist, 2001, 149(3): 589-598 (doi: 10.1046/j.14698137.2001.00038.x).

36. Morakotkarn D., Kawasaki H., Seki T. Molecular diversity of bamboo-associated fungi isolated from Japan. FEMS Microbiology Letters, 2006, 266(1): 10-19 (doi: 10.1111/j.15746968.2006.00489.x).

37. Wei Y.K., Gao Y.B., Zhang X., Su D., Wang Y.H., Xu H., Lin F., Ren A.Z., Chen L., Nie L.Y. Distribution and diversity of Epichloë/Neotyphodium fungal endophytes from different populations of Achnatherum sibiricum (Poaceae) in the Inner Mongolia Steppe, China. Fungal Diversity, 2007, 24: 329-345. 
38. Zhang X., Ren A.Z., Wei Y.K., Lin F., Li C., Liu Z.J., Gao Y.B. Taxonomy, diversity and origins of symbiotic endophytes of Achnatherum sibiricum in the Inner Mongolia Steppe of China. FEMS Microbiology Letters, 2009, 301(1), 12-20 (doi: 10.1111/j.1574-6968.2009.01789.x).

39. Sánchez Márquez S., Bills G.F., Zabalgogeazeoa I. The endophytic mycobiota of the grass Dactylis glomerata. Fungal Diversity, 2007, 27: 171-195.

40. Гагкаева Т.Ю., Гаврилова О.П., Орина А.С., Гогина Н.Н. Чрезвычайная ситуация 2019 г. и болезни зерна в Амурской области. Защита и карантин растений, 2020, 8: 19-21.

41. Li F., Yoshizawa T. Alternaria mycotoxins in weathered wheat from China. Journal of Agricultural and Food Chemistry, 2000, 48(7): 2920-2924 (doi: 10.1021/jf0000171).

42. Омельченко М.Д., Жердев А.В., Николаев И.В., Жалиева Л.Д., Буханистая Г.Ф., Баттилани П., Дзантиев Б.Б. Оценка влияния агротехнических и метеорологических факторов на загрязнение зерна фузариотоксинами в агроценозах пшеницы из разных климатических зон РФ. Аграрная Россия, 2013, 1: 2-9 (doi: 10.30906/1999-5636-2013-1-2-9).

43. Кононенко Г.П., Буркин А.А., Зотова Е.В. Микотоксикологический мониторинг. Сообщение 2. Зерно пшеницы, ячменя, овса, кукурузы. Ветеринария сегодня, 2020, 2(33): 139145 (doi: 10.29326/2304-196X-2020-2-33-139-145).

44. Sulyok M., Berthiller F., Krska R., Schuhmacher R. Development and validation of a liquid chromatography/tandem mass spectrometric method for the determination of 39 mycotoxins in wheat and maize. Rapid Communications in Mass Spectrometry, 2006, 20(18): 2649-2659 (doi: 10.1002/rcm.2640).

45. Schenzel J., Forrer H.R., Vogelgsang S., Bucheli T.D. Development, validation and application of a multi-mycotoxin method for the analysis of whole wheat plants. Mycotoxin Research, 2012, 28(2): 135-147 (doi: 10.1007/s12550-012-0125-z).

46. Uhlig S., Vikøren T., Ivanova L., Handeland K. Ergot alkaloids in Norwegian wild grasses: a mass spectrometric approach. Rapid Communications in Mass Spectrometry, 2007, 21(10): 1651-1660 (doi: 10.1002/rcm.3005).

47. Гаврилова О.П., Орина А.С., Гогина Н.Н., Гагкаева Т.Ю. Совместная встречаемость метаболитов грибов Alternaria и Fusarium, ассоциированных с зерновыми культурами. Российская сельскохозяйственная наука, 2020, 6: 20-23 (doi: 10.31857/S2500262720060058).

\title{
Всероссийский НИИ ветеринарной санитарии,
} гигиены и экологии - филиал ФГБНУ ФНЦ ВИЭВ РАН, Поступила в редакцию 123022 Россия, г. Москва, Звенигородское ш., 5, e-mail: kononenkogp@mail.ru $₫$, ezotova63@gmail.com, aaburkin@mail.ru

\section{5 мая 2021 года}

Sel'skokhozyaistvennaya biologiya [Agricultural Biology], 2021, V. 56, № 5, pp. 958-967

\section{ADVANCES IN MYCOTOXICOLOGICAL RESEARCH OF FORAGE GRAIN CROPS}

\author{
G.P. Kononenko $\bowtie$, E.V. Zotova, A.A. Burkin
}

All-Russian Research Institute for Veterinary Sanitation, Hygiene and Ecology - Branch of FSC ARRIEV RAS, 5, Zvenigorodskoe sh., Moscow, 123022 Russia, e-mail kononenkogp@mail.ru ( $\square$ corresponding author), ezotova63@gmail.com, aaburkin@mail.ru

ORCID:

Kononenko G.P. orcid.org/0000-0002-9144-615X Burkin A.A. orcid.org/0000-0002-5674-2818

Zotova E.V. orcid.org/0000-0002-1479-8602

The authors declare no conflict of interests

Received May 25, 2021

doi: 10.15389/agrobiology.2021.5.958eng

\section{Abstract}

Recently, production of forage from the vegetative mass of grain crops has been steadily growing in Russia (Z.L. Fedorova, L.V. Romanenko, 2016; V.V. Popov, 2017; E.A. Volkova et al., 2018). For the successful and safe use of these products, it is extremely important not only to strictly observe the recommended terms, mowing height, drying conditions and technology of silaging grainstem mass, but also to have the most complete information about the sanitary quality of raw materials. The study of the peculiarities of contamination by toxigenic microscopic fungi and mycotoxins of wild and cultivated cereals has already begun (G.Yu. Laptev et al., 2014; A.A. Burkin, G.P. Kononenko, 2015; G.P. Kononenko et al., 2015; E.A. Yildirim et al., 2019). However, this aspect has not been studied with a focus on forage crops. This work, for the first time, presents data on contamination of vegetative grain crops with toxic metabolites of microscopic fungi and on changes in the content of mycotoxins over phases of plant development and in ears at the beginning of grain maturation. The aim of this work was a mycotoxicological study of common barley (Hordeum vulgare L.), soft wheat 
(Triticum aestivum L.), and oats (Avena sativa $\mathrm{L}$.) during in the periods optimal for hay harvesting and in unripe ears of wheat and barley. The samples (spring barley $H$. vulgare cv. Vladimir, spring soft wheat $T$. aestivum cv. Ivolga, and oats A. sativa cv. Skakun) were collected from April 24 to August 11, 2019 (the fields of the Russian State Agrarian University - Moscow Timiryazev Agricultural Academy and the Williams Federal Scientific Center for Feed Production and Agroecology, Moscow Province). Beginning of tillering-ligule formation was noted as period 1, opening of the flag leaf envelope and appearance of the awns above the ligule-early milk ripeness - as period 2. At the stage of grain maturation, from the aboveground parts cut $3-5 \mathrm{~cm}$ from the soil surface the ears were separated. The concentrations of T-2 toxin (T-2), deoxynivalenol (DON), zearalenone (ZEN), fumonisins (FUM), alternariol (AOL), roridin $A(R O A)$, aflatoxin $\mathrm{B}_{1}\left(\mathrm{AB}_{1}\right)$, sterigmatocystin (STE), cyclopiazonic acid (CPA), emodin (EMO), ochratoxin A (OA), citrinin (CIT), mycophenolic acid (MPA), PR toxin (PR), and ergot alkaloids (EA) were measured by indirect competitive enzyme immunoassay (ELISA) test. The detected load of mycotoxins was generally low. AOL, EMO were present in small and comparable amounts of $15-32 \mu \mathrm{g} / \mathrm{kg}$ and $14-29 \mu \mathrm{g} / \mathrm{kg}$, as well as CPA and EA with wider ranges of variation, from 34 to $180 \mu \mathrm{g} / \mathrm{kg}$ and from 2 to $115 \mu \mathrm{g} / \mathrm{kg}$. Fusariotoxins T-2, DON, and ZEN appeared in single samples, and FUM was not detected. ROA was also absent, and PR was extremely rare and detected only in one sample of wheat. In all crops, tens of $\mu \mathrm{g} / \mathrm{kg}$ MPA and STE were found, and $\mathrm{AB}_{1}$ amounted to $1-3 \mu \mathrm{g} / \mathrm{kg}$. Combined contamination of OA and CIT occurred only in barley (more often at tillering and ligule formation), while OA contamination occurred, though rare, in wheat and oats at the levels close to the detection limit. Lower contamination by mycotoxins was characteristic of vegetative oat plants compared to barley and wheat, which is practically important since fodder oat is popular as a green fodder for preservation, both separately and in crop mixtures. Wheat and barley ears at the beginning of grain maturation were noticeably different from the aboveground parts of the plants and showed a uniform tendency to reduce the frequency of mycotoxin detection to single cases or complete absence while maintaining the occurrence of EMO.

Keywords: wheat, barley, oat, plant biomass, mycotoxins, ELISA. 